\title{
ЛИЧНОСТЬ VERSUS ПОСТЧЕЛОВЕК
}

\section{В. И. МИСЬКЕВИЧ}

Белорусский государственный университет информатики и радиоэлектроники, 2. Минск, Беларусь

Нередко христианскую культуру сводят к культуре греко-римско-иудейской, специфически промысленной и прожитой постантичной Европой. Ее ключевой интенцией было стремление постичь феномен человека в аспекте его подобия образу Бога. Отсюда то внутреннее напряжение и динамизм социокультурной жизни западного общества, которое нашло свое выражение в формировании идеологии гуманизма.

Гуманизм - это идеология самоутверждения западного человека. Ее исходные принципы были сформулированы еще в античности в герметическом корпусе. Однако понастоящему затребованной временем она оказалась в эпоху Возрождения. По сути, гуманизм (с его базисной идеей антропоцентризма) принес с собой кардинальную трансформацию мировоззрения. В прежние времена (повсеместно) социальное и человеческое бытие находило оправдание и обретало смысл только в контексте отношения к целому (Космосу, Брахману, Дао, Небу, Логосу, Богу, Природе). Будучи его частью (эманацией, проявлением, творением), социальный субъект соотносил с ним свое существование, обустраивал жизнь, поддерживал порядок и верил в незыблемость устоев. Гуманистическое мировоззрение, поставив в центр бытия человека, «обессмыслило» целое. Посредством пантеистической, деистической, а затем и атеистической реинтерпретации места и статуса в мироздании Бога, природа стала пониматься просто как совокупность множества разнообразных и разнородных вещей. И очень быстро стала пробным камнем для испытания нового видения бытия «титанами Возрождения» (Ф. Энгельс), превратившись в объект приложения творческих сил и способностей человека в качестве свободного славного мастера, творца. С течением времени были изобретены инструменты практической реализации амбиций ренессансного человека - наука, техника (технологии), практикоориентированная система образования, социальные революции и реформы, новая система права и правовое государство. На волне утверждения новой идеологии (некоторые авторы называют гуманизм светской религией западного мира) были разработаны различные социально-философские и политические проекты переустройства социума в интересах человека. Некоторые из них (либеральный, социалистический, эволюционно-евгенический) были положены в основу известных социальных практик и экспериментов XIX-XX вв. Наиболее жизнеспособным среди них оказался либералистский с его идеалами гуманизма - прав и свобод человека, самоценности личности, свободного рынка.

Однако была и восточная ветвь христианства, связанная с Византией и дочерними по отношению к ней церквями. Ключевые интенции этого направления христианской культуры были обусловлены ее подчиненным, служебным положением по отношению к власти кесаря. Отсюда, с одной стороны, ее склонность к мистицизму, а с другой - замкнутость на обрядность и ритуализм. Реальная действительность, реальный человек с его мирскими слабостями и запросами выпадали из поля ее мировосприятия, точнее, критической рефлексии и оценок. Доминирующей была установка на проповедь смирения и покорности властям. Не случайно поэтому (лишь один частный пример) церковь как социальный институт и класс священников не только не помогли российскому самодержавию в критический момент, но и сами подверглись жестоким репрессиям со стороны большевиков и... православного люда. Вместе с тем нужно подчеркнуть важную роль поместных 
православных церквей, православной культуры в сохранении национальной идентичности целого ряда наших соседей. Нам, народу Беларуси, в этом плане, в силу известных причин, не повезло совершенно.

Сегодня мир стоит перед невиданными в истории вызовами. По сути, на кону вопрос выживания человечества как вида. Нарастающие противоречия множатся, и классические представления о человеке (даже с учетом психоаналитической коррекции) приходят во все большее противоречие с реалиями современности. Обычный индивид просто «выпадает» из ритма и требований стремительно утверждающегося информационного общества. Комфорта и вещей становится все больше, а счастья и покоя - меньше. Традиционные ценности (семья, брак, образы мужчины и женщины, гендерные роли, отношение к труду, свобода, патриотизм, память о деяния предков, христианское наследие и т. п.) девальвируются и извращаются. (Реклама в ЦУМе г. Минска: «Неважно где и кем вы работаете. Важно, где и как вы отдыхаете»). Истончение духовно-ценностного, социокультурного и психоэмоционального начала в «Я», межличностных отношения, идеалах и смыслах как неких эпифеноменов ведет к упрощенному пониманию природы человека, его места и предназначения в универсуме.

Сегодня за «ваяние» нового типа Ното, адекватного вызовам времени, берется наука. В фокусе интересов BNICS-технологий - конструирование «постчеловека». «Постчеловек»это уже не социокультурный феномен (как полагали гуманисты прежних времен)), а некий технический проект (задание). Предлагаются разные варианты его реализации - от создания почти бессмертных антропоидов и киборгов до неорганических носителей искусственного интеллекта. Посередине находим неоевгеническую концепцию генетического «выведения» сверхлюдей, обладающих суперспособностями и сверхвозможностями. Однако подобного рода перспектива, надо полагать, будет доступно лишь немногим - тем, кто при деньгах и власти.

А большинство должен утешить современный вариант техногуманизма в виде датаизма (от анг. data - данные, сведения). Его адепты убеждены, что тотальная цифровизация всего и вся, включая все доступные алгоритмизации, характеристика и параметры конкретного индивида (генетические, соматические, физиологические, психологические, ментальные, потребностно-мотивационные и т. д.), откроют для него двери в очередной «новый дивный мир» (О. Хаксли). Предполагается, что искусственный интеллект, извлекая из информационных облаков необходимую подноготную информацию о некоем NN, в любое время сможет предложить ему готовое и оптимальное решение его проблем. Муки сомнения и неопределенности, бремя выбора и ответственности не должны травмировать его психику.

Что здесь существенно: наука, инженерия и благословляющая их идеология техногуманизма смотрят на проблему кардинальной трансформации человека как сугубо техническую задачу, вполне реальную и в принципе осуществимую. Ее решение связывается с соответствующим финансированием проектов, дальнейшими исследованиями, конструированием подходящих материалов, созданием новых технологий и разработкой все более совершенных алгоритмов.

Однако грань между добром и злом, как известно, тонкая, а благими намерениями вымощена дорога известно куда. Тот факт, что некая неведомая мне инстанция будет следить за моим, скажем, здоровьем и вовремя предупреждать об отклонениях от нормы, давать подсказки решения житейских и межличностных проблем и т. п., вроде, с одной стороны, благо. И если видеть только ее, то почему бы и нет. Но есть и другая сторона - в виде моей личности, самосознания, воли, свободы, выбора и ответственности за свои действия и собственное бытие. Сомнительно, что алгоритмы могут высвободить человека из-под бремени жизни и ее «клешей» (обусловленностей). 
Дело в том, что в обозримом будущем никуда не деться от реальных «исторических» людей с их повседневными проблемами и запросами, коих на Земле скоро будет под 10 млрд. человек. Бытие каждого из них обусловлено сонмом различных детерминаций - как внешних, так и внутренних. Внешние идут от природы, социума, культуры, языка, мировоззрения, общественной психологии, традиций, навязываются СМИ, системой образования, модой, рекламой, семьей, авторитетами и т. д. Внутренний детерминизм индивида связан с его соматикой, генетически обусловленными склонностями, особенностями характера и темперамента, вытесненными влечениями, силой либидо и механизмами защиты, комплексами неполноценности, сформированными привычками и т.д. Мозг каким-то непостижимым образом сводит воедино все это многообразие импульсов («клешей») воедино и обеспечивает приспособление человека к среде (или не обеспечивает). И каждый, как о призе, мечтает о счастье, понимая его на свой лад.

Длительные позитивные состояния умственного и душевного (психоэмоционального) равновесия или воодушевления и вдохновения выпадают на долю немногих и связаны с капризами Фортуны (случаются баловни судьбы) или умением человека самостоятельно реализовать свой жизненный проект. Однако обычный простой обыватель о существовании Пути (так жизненный проект именуется на Востоке) не подозревает. В школе и университетах о нем не говорят и не учат, за исключением мимолетных реминисценций на занятиях по философии. Поэтому для достижения комфортного и желаемого состояния души просто homo использует всевозможные подручные паллиативные средства изменения сознания - никотин, алкоголь, еду, сахар, наркотики, разного рода экстрим, эмигрирует в Интернет и т. д. Высвобожденное такими способами напряжение бессознательного и потаенного влечения приносит эйфорию, удовольствие и мимолётную релаксацию. Как бы моменты счастья. Некоторое количество повторений - и условный рефлекс в виде устойчивой вредной привычки сформирован. Еще одним способом изменения сознания является толпа. Пробуждаемый ею стадный инстинкт в человеке способствует возникновению у него чувства квазипринадлежности и квазизащищенности, якобы сопричастности надличностным целям и идеалам. Сегодня это, например, фанаты всех мастей. А раз есть массовая потребность в поклонении, то и за кумирами дело не стоит. Бизнес давно уже поставил их производство на поток. Таким образом, формы и способы отчуждения и самоотчуждения индивида в современном мире множатся, а вот Пути к себе, есть ощущение, сознательно блокируются. Поясню эту мысль.

Человек всегда обустраивался в мире не только посредством материальных, но и образно-символических практик (мифа, религии, искусства, традиции). В истории культур разных эпох и народов человеческое бытие всегда мыслилось «объемно», как имеющее «корни» (традиции), так и «вершину» (Бог). Сегодня это бытие «сплющилось», представляется плоскостным, т. е. безосновным и бессмысленным. Как существование Арлекина: «без имени и, в общем, без судьбы». Другими словами, традиции для большинства утратили свою жизненную силу и воспринимаются массой просто как элементы фольклора и реликвии прошлого. Они могут быть интересны туристам и на этом интересе можно делать бизнес. Что касается «вершины», то для западного человека «Бог умер» естественной кончиной еще в XIX в., а на востоке христианского мира его насильственно «похоронили» большевики в XX в. Между тем схлопнувшийся и превратившийся в плоскость мир человеческого бытия нужно чем-то заполнять. И он заполняется - гипермаркетами, шоу-аренами, «звездами», вещами, идеологиями, рекламой, симулякрами, виртуальностями, химерами, утопиями и проч.

Одна из таких утопий (в различных модификациях) связана с моделированием нового образа человека - постчеловека. Однако этот образ, как отмечалось выше, осмысливается техницистски и технологически. За скобками его остается то содержание, которое, 
собственно, и специфицирует человека. И лучше Конфуция о нем не скажешь : «Человек измеряется не тем, что он есть с ног до головы, а тем, что он есть с головы до неба». И, спрашивается, как это его измерение можно отрефлексировать и тем более оцифровать? Вопрос риторический. Вне рефлексии, скажем по старинке, технократов остается и тугой узел мировоззренческих, нравственных, психологических, социальных, правовых и педагогических проблем, вне которых немыслима жизнь человека.

В этих условиях старинный педагогический вопрос : «Кого, чему и как учить» приобретает особую актуальность. И если система образования сегодня, по определению, это территория опережающего развития, то проблема человека, его развитие в «горизонте личности» (М. Библер) должна быть для этой «территории» столь же важной, как цифровые и интеллектуальные технологии, искусственный интеллект и интеллектуализация образования. «Оцифровать» мозг и психику молодого человека под специальность несложно. К такой перспективе они уже давно подготовлены. Процесс цифровой социализации личности начинается сегодня чуть ли не с младенчества. Широко известны и связанные с нею последствия [2]. В этой связи принципиальное значение имеет вопрос переосмысления роли и значения образования в аспекте формирования у учащихся не только hard skills, но и soft skills. Дело в том, что формирование и развитие «мягких умений» (т. е. социальных, коммуникативных, волютивных и эмоциональных качеств) в отличие от «твёрдых» профессиональных компетенций практически не являются предметом учебных программ.

В данном вопросе есть моменты принципиального характера. Один из них связан с интерпретацией понятий «знание» и «информация», имеющих важнейшее значение для образовательных практик. В научной литературе существуют разные мнения на предмет соотношения их содержания и объемов, способов существования и форм представления [1]. Большинство исследователей момент общности усматривают в том, что знание и информация выражаются в знаке. Действительно, философские трактаты, романы, стихи, юридические акты, технические инструкции, учебные пособия, речи ораторов и т. д. можно рассматривать и как знание, и как информацию. Вместе с тем знание может быть и невербализованным, знаково неоформленным, быть сокровенным, неявным, неотрефлектированным, интуитивным. Особенность знаний (и в виде знаковых систем, и неявных представлений) заключается в том, что они адресуются человеку как целостном субъекту, т. е. его уму, сердцу, чувствам, вере, могут накладывать на него определенную ответственность и т. д. Усвоение (интериоризация) индивидом знаний в процессе социализации является важнейшей предпосылкой его развития в горизонте личности. Поэтому «сила» знаний не только в преобразовании внешней среды, но и преображении человека.

Информация (например, в виде последовательности или комбинации сигналов определенной структуры) имеет не только человеческую (социокультурную) знаковосимволическую форму существования, но и природную. Последняя может определяться мерой энтропии материального объекта. В этом смысле обмен энергией, веществом и информацией является универсальной предпосылкой самоорганизации и развития всех материальных систем, включая биоту и социум. В природных взаимодействиях информация (скажем, закодированная в ДНК) является исходной матрицей самоконструирования живого организма в процессе онтогенеза. Аналогичным образом она «срабатывает» и в воспроизводстве социальных структур и отношений (с тем отличием, что хранителем социального «генома» выступает культура). Информация превращается в знание законов природы («первой», «второй», а сегодня и «третьей»), социальных и культурных процессов и человеческих действий при условии ее раскодирования познающим субъектом. Обретение знаний, их умножение шло (и идет) через метод проб и ошибок, «расколдовывание природы» (М. Вебер) философией, научные исследования, вариабельные социальные практики, техническое и художественное творчество и т. д. 
Знания многообразны. Но для систем образования особое значение имеют научные знания. Их отличительная особенность - объективность. В этом смысле они ценностно нейтральны. Сказанное справедливо прежде всего по отношению к естественнонаучному, математическому и техническому знаниям. Вместе с тем здесь нужна оговорка: ценностная нейтральность вышеназванных видов научных знаний принципиально важна в социальном аспекте. Но на индивидуально-личностном уровне объективные научные знания сопрягаются с эмоциональным строем и ценностными представлениями их носителей. В этом плане и говорят о нравственной ответственности ученых и инженеров за результаты их деятельности.

Социогуманитарные знания (история, социология, экономика, языкознание, педагогика, культурология, искусствоведение, психология, герменевтика, социология, философия и т. д.) по самой природе своей так или иначе связаны с мировоззрением, идеологией, верой, социальными чувствами, идеями и идеалами людей. Их предназначение ориентировать социум и индивидов в истории и жизненном мире. В социальном аспекте изучать и знать историю и культуру нужно не для того, чтобы предсказывать будущее, как справедливо замечает в своем бестселлере Н. Харари, а чтобы освободиться от прошлого и задуматься над перспективами альтернатив [3, с. 81]. Эта задача сегодня более чем актуальна. На индивидуальном же уровне гуманитаристика (комплекс философских и научных социокультурных знаний о человеке) является важнейшим (наряду с религией) каналом самопознания и самопонимания индивида. Следовательно, продуманная оптимизация социогуманитаного блока должна быть сопряжена с ясным пониманием целей и задач его изучения и реальным «вкладом» в развитие личности молодого человека, осознанного культивирования у него не только hard skills, но и soft skills.

\section{Литература}

1. Карпов, А. О. Общество знаний: знание против информация // Философские науки. 2017. - № 12. - С. 19-36.

2. Малыхина, Г. И. Цифровая социализация в условиях дистанционного обучения / Г. И. Малыхина, В. И. Миськевич // Дистанционное обучение - образовательная среда XXI века : материалы XI Международной научно-методической конференции (Республика Беларусь, Минск, 12-13 декабря 2019 года) / редкол.: В.А. Прытков [и др.]. Минск : БГУИР, 2019 - С. 193-194.

3. Харари, Ю. Н. Sapiens. Краткая история человечества / Юваль Ной Харари : [пер. с англ. А. Сумм]. - М. : Синдбад, 2019. - 520 с.

В статье рассматриваются проблемы социокультурной динамики и перспективы homo sapiens в аспекте фундаментальной трансформации традиционных ценностей в условиях информационного общества. Акцентируются некоторые важные проблемы современной системы образования.

The article deals with the problems of socio-cultural dynamics and prospects of homo sapiens in the aspect of fundamental transformation of traditional values in the information society. Some important problems of the modern education system are emphasized. 